\title{
A Model for Simulating the Thermal and Electrical Production of Small-Scale Solid-Oxide Fuel Cell Cogeneration Systems within Building Simulation Programs
}

\author{
Ian Beausoleil-Morrison, PhD Adrian Schatz, PE François Maréchal, PhD \\ Member ASHRAE
}

Received January 15, 2006; accepted March 30, 2006

A new model for predicting the thermal and electrical performance of solid-oxide fuel cell (SOFC) cogeneration devices for residential buildings has been developed and demonstrated. This is a system-level model that considers the thermodynamic performance of all components that consume energy and produce the thermal and electrical output of the SOFC-cogeneration device. The model relies heavily upon empirical information that can be acquired from the testing of coherent systems or components and is designed for operation at a time resolution that is in the order of minutes. Hence, it is appropriate for use in whole-building simulation programs, where it can be applied to assess the energy and greenhouse gas emission benefits of this nascent technology.

\section{INTRODUCTION}

Residential cogeneration is an emerging technology with a high potential to deliver energy services with increased efficiency and environmental benefits. The concurrent production of electricity and heat from a single fuel source can reduce primary energy consumption and associated greenhouse gas emissions. Reductions in combustion by-products, such as nitrogen oxides and hydrocarbons, are also a possibility. The decentralized production of electricity also has the potential to reduce electrical transmission and distribution congestion and to alleviate utility peak demand problems. A number of manufacturers worldwide are developing residential-scale cogeneration devices based upon fuel cells, internal combustion engines, and Stirling cycles (Knight and Ugursal 2005).

The effective exploitation of the cogeneration device's thermal output for space heating, space cooling, and/or heating domestic hot water (DHW) is critical to realizing high levels of overall energy efficiency and the associated environmental benefits. Consequently, the performance of these devices will be highly dependent upon how the cogeneration device is integrated to service the host building's thermal and electrical demands. Therefore, in order to accurately assess performance, it is imperative that models of cogeneration devices be incorporated into whole-building simulation tools that account for the interactions between the building and its environment, the occupants, the thermal and electrical production and distribution systems, and energy management and control systems.

These factors motivated the formation of Annex 42 of the International Energy Agency's Energy Conservation in Buildings and Community Systems Programme (IEA/ECBCS). This

Ian Beausoleil-Morrison is head of Building Simulation Research, CANMET Energy Technology Centre, Natural Resources Canada, Ottawa, Ontario, Canada. Adrian Schatz was formerly with Sulzer Hexis AG, Winterthur, Switzerland. François Maréchal is with the Laboratory for Industrial Energy Systems, Institute of Energy Sciences, Ecole Polytechnique de Lausanne, Lausanne, Switzerland. 
international collaborative project aims to develop, validate, and implement models of cogeneration devices for whole-building simulation programs.

This paper describes the mathematical model that IEA/ECBCS Annex 42 developed for simulating the performance of solid oxide fuel cell (SOFC) cogeneration devices within whole-building simulation programs. This model is based upon the earlier work of Beausoleil-Morrison et al. $(2002,2005)$ and the modeling experiences of Sulzer-Hexis and other IEA/ECBCS Annex 42 participants. The paper also describes the implementation of the model into a building simulation program, demonstrates its application, and briefly describes ongoing model calibration and validation efforts. The paper concludes with recommendations for future work.

\section{SOFC COGENERATION}

Fuel cells are energy-conserving devices that directly convert chemical energy to electrical energy. This is accomplished through the electrochemical oxidation of a fuel and the electrochemical reduction of oxygen. These electrochemical reactions occur at electrodes that are continuously fed with fuel and oxygen and are separated by an electrolyte layer.

SOFCs use a solid metal oxide as the electrolyte. These show particular promise for residential cogeneration applications because of their high operating temperature $\left(600^{\circ} \mathrm{C}\right.$ to $\left.1000^{\circ} \mathrm{C}\right)$ and their ability to operate directly on natural gas. These temperatures are sufficient to internally reform the gas's constituent hydrocarbon molecules (methane, ethane, propane, etc.) to hydrogen and carbon monoxide, which are then supplied to the electrode, where they are partially oxidized with the oxygen crossing the electrolyte. Internal reforming avoids either the need to deliver and store hydrogen at the building site or the cost, energy, and space requirements of an external fuel reformer. The second advantage of the SOFC's high operating temperature is the production of thermal energy at temperatures that can be exploited for space heating, space cooling, and/or DHW heating.

The interested reader is referred to Singhal and Kendall (2003) for a thorough review of SOFC technology and to Ellis and Gunes (2002) for a discussion on the use of fuel cells for building cogeneration.

It is important to note that the fuel cell stack itself is only a single component within a complex energy conversion system. Figure 1 illustrates one possible system configuration of an SOFC cogeneration device. ${ }^{1}$ Besides the fuel cell stack (shown in grey), the system might include an afterburner to combust unreacted fuel; an air filter and preheater; a fuel desulfurizer, preheater, prereformer, and reformer; and water preparation. A compressor may be required to supply pressurized fuel, while a blower will likely be present to supply air to provide oxygen to support the electrochemical and combustion reactions. A pump may also be required to supply liquid water for steam reformation purposes. A battery could be used for buffering the fuel cell stack's DC electrical production and for meeting load transients, and the system will include a power conditioning unit to convert the electrical output to AC. All SOFC-cogeneration systems will include a heat recovery device that transfers the heat of the hot product gases to the building's HVAC system. Some systems may include an integrated auxiliary burner that is activated when the fuel cell cannot satisfy the building's thermal loads.

\section{MODEL TOPOLOGY}

Many detailed SOFC models are presented in the literature. However, most of these are not well suited for the purposes of IEA/ECBCS Annex 42. Many of these models focus on single

\footnotetext{
${ }^{1}$ Some energy flows (e.g., thermal inputs to the desulfurizer and fuel preheater) are not illustrated in the figure for the sake of clarity. Also, intra-control-volume energy flows are not considered within the model, as elaborated in the following sections.
} 


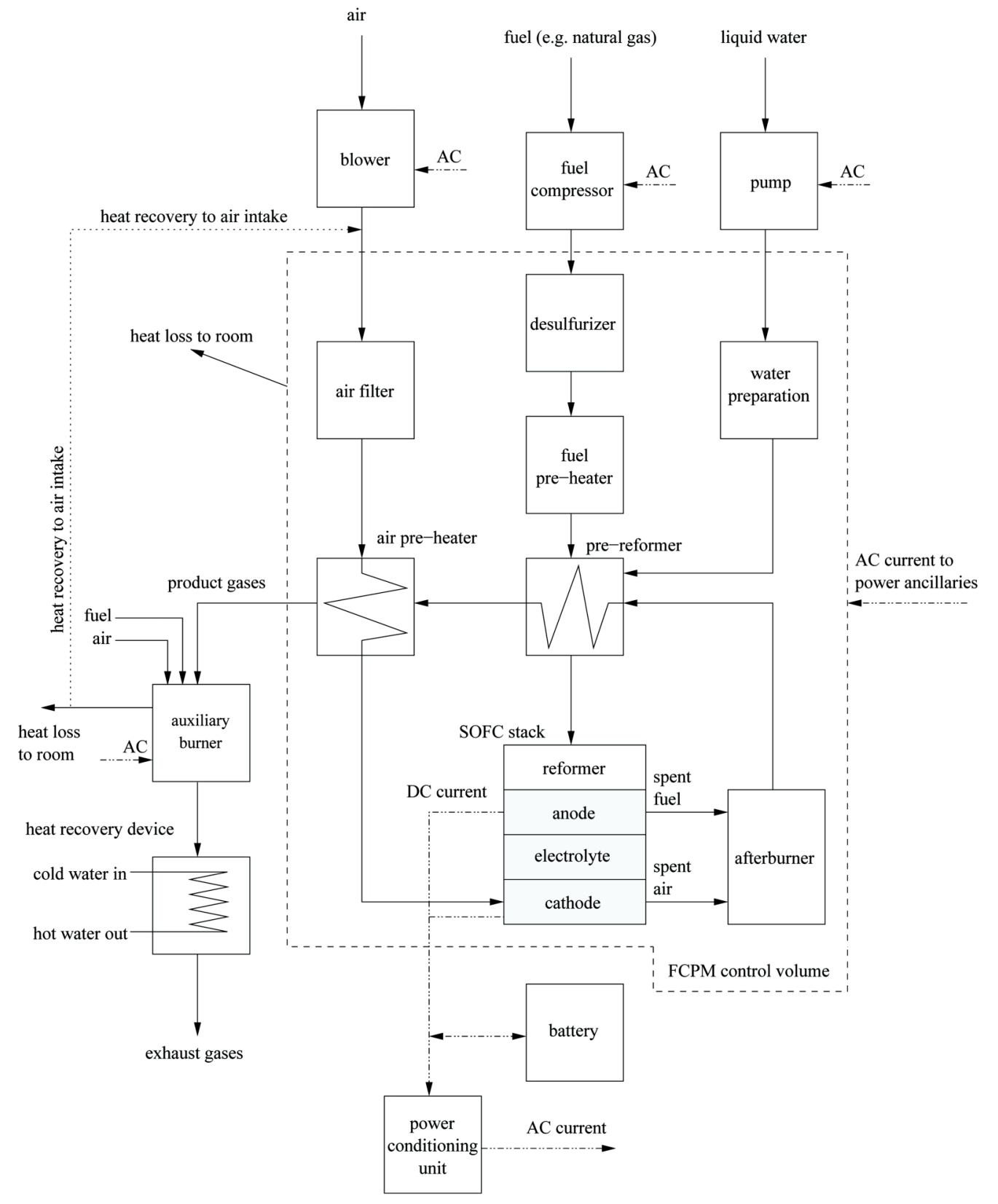

Figure 1. One possible system configuration of a SOFC-cogeneration device. 
cells or stacks of cells while other components (refer to Figure 1) are left untreated (e.g., Beale et al. [2003] and Bove et al. [2005a]). Other models (e.g., Van herle et al. [2004]) focus on system design aspects and balance of plant without considering the part-load operation and the dynamic behavior of the complete system.

In contrast, IEA/ECBCS Annex 42 requires a model that considers the thermodynamic performance of the complete system. This SOFC-cogeneration model will be coupled to models of associated HVAC components, such as hot-water storage, peak-load boilers and heaters, pumps that circulate hot or cold water to hydronic heaters located in the rooms or to air-handling units, fans that circulate conditioned air to the rooms, and heat exchangers. In turn, these models, representing the building's coherent HVAC and electrical production systems, will be coupled to models that predict the building's thermal and electrical demands.

Numerous researchers have examined the performance of this complete thermodynamic system (Braun 2002; Sicre et al. 2005; Dorer et al. 2005; Hawkes and Leach 2005). However, in these contributions the SOFC-cogeneration device has been modeled using a performance map (derived either from empirical evidence or from detailed modeling performed outside the context of whole-building simulation) that decouples the electrical and thermal performance of the cogeneration device from the rest of the thermodynamic system.

As argued in the introduction to this paper, there is a need for an intermediate-level model that operates at the resolution of whole-building simulation. Such an approach would account, on a time-step basis, for the interactions between the building and its environment, the occupants, the thermal and electrical production and distribution systems, and energy management and control systems. Furthermore, it is argued that this model should discretize the SOFC-cogeneration system into groupings of components that compose major subsystems, such as those that produce electrical power, supply air, and capture heat from the hot product gases, etc. In this manner, once the model is calibrated for a specific SOFC-cogeneration device, analyses can be conducted to explore the benefits of improving the performance of individual subsystems. For example, the impact of improving the heat recovery device upon overall system performance can be simulated without recalibrating the portions of the model that represent the other subsystems. Additionally, such a structure facilitates the future development of more detailed modeling methods for specific subsystems.

To address these needs, a model has been developed that discretizes the SOFC-cogeneration system into nine control volumes:

1. The fuel cell power module (FCPM), which includes the stack, the afterburner, and the other components enclosed by the dashed line in Figure 1.

2. The air supply blower.

3. The fuel supply compressor.

4. The water pump.

5. An auxiliary burner.

6. An exhaust-gas-to-water heat exchanger.

7. A battery system for electrical storage.

8. A DC-AC power conditioning unit.

9. A dilution air system with optional heat recovery ventilator (not shown in Figure 1), as used in some systems to draw air through the cabinet to control skin losses to the containing room.

Each control volume is modeled in as rigorous a fashion as possible given the constraints of computational efficiency and the need to calibrate model inputs based upon the testing of coherent systems. (It is worth noting that the equations described in this paper could be recalculated over 100,000 times to perform a single annual simulation.) The following sections describe 
some of the methods used for resolving the three control volumes that are most critical from the perspective of predicting the thermal and electrical production: the FCPM, the auxiliary burner, and the exhaust-gas-to-water heat exchanger. The interested reader is referred to Beausoleil-Morrison (2005) for a complete treatment of the model.

\section{FUEL CELL POWER MODULE}

As described above, the FCPM control volume is drawn to encompass the fuel cell stack as well as a number of the balance of plant components. This is done for the following pragmatic reasons:

- Product-specific information regarding the arrangement of components is not required, an important consideration since many manufacturers consider this information to be proprietary.

- The model can represent SOFCs with indirect internal reforming (hydrocarbons are reacted to $\mathrm{H}_{2}$ and $\mathrm{CO}$ at a catalyst that is physically separated but thermally coupled to the anode) or direct internal reforming (hydrocarbons are reacted at the anode).

- The model can represent both planar and tubular SOFC designs.

- Inputs to the model can be derived from empirical measurements made on either individual subsystems or from coherent system testing. Alternatively, the model inputs can be derived from highly detailed mechanistic subsystem modelling that is performed independently from the building simulation programs.

\section{Energy Balance}

Referring to Figure 1, the following energy balance can be written for the control volume representing the FCPM (the dashed line):

$$
\dot{H}_{\text {fuel }}+\dot{H}_{\text {air }}+\dot{H}_{\text {liq-water }}+P_{e l, \text { anc-AC }}=P_{e l}+\dot{H}_{F C P M-c g}+q_{\text {skin-loss }}
$$

where $\dot{H}_{\text {fuel }}, \dot{H}_{\text {air }}$, and $\dot{H}_{\text {liq-water }}$ are the total enthalpy flow rates of the fuel, air, and liquid water (for steam reformation) introduced to the control volume. $\dot{H}_{F C P M-c g}$ is the total enthalpy flow rate of the product gases exiting the control volume and entering the auxiliary burner. These product gases result from the electrochemical and combustion reaction of the fuel and air and also include the unreacted fuel and air constituents and the water vapor that is generated from the liquid water that is supplied for steam reformation. $q_{\text {skin-loss }}$ represents the parasitic thermal losses in the form of radiation and convection to the containing room. $P_{e l}$ is the net DC electric power produced by the FCPM, while $P_{e l, a n c-A C}$ is the power draw of the ancillaries that are included within the control volume and that are powered by AC electricity that is supplied to the cogeneration device. (All terms in Equation 1 are expressed in watts.) The total enthalpy flow rates of the gas streams in Equation 1 represent summations of the enthalpies of their constituent gases, e.g.,

$$
\dot{H}_{f u e l}=\sum_{i}\left(\dot{N}_{i} \hat{h}_{i}\right)_{f u e l}
$$

where $\dot{N}_{i}$ is the molar flow rate $(\mathrm{kmol} / \mathrm{s})$ and $\hat{h}_{i}$ is the molar enthalpy $(\mathrm{J} / \mathrm{kmol})$ of fuel constituent $i\left(\mathrm{CH}_{4}, \mathrm{C}_{2} \mathrm{H}_{6}, \mathrm{H}_{2}, \mathrm{CH}_{3} \mathrm{OH}, \mathrm{CO}_{2}, \mathrm{~N}_{2}\right.$, etc. $)$.

Standardized enthalpies are used since chemical reactions are occurring within the FCPM. This ensures that the enthalpy of each reactant or product is properly related to the enthalpies of other elements and compounds by using a standard reference state. By convention, the standard 
state is taken to be $25^{\circ} \mathrm{C}$ and 1 atmosphere pressure and the enthalpies of all elemental substances (e.g., $\mathrm{O}_{2}, \mathrm{H}_{2}$ ) are taken to be zero at the standard state.

For convenience, the enthalpy of each reactant or product is expressed as a sum of its enthalpy at the standard state (i.e., the standard enthalpy of formation) and the deviation between its enthalpy and that at the standard state,

$$
\hat{h}_{i}=\Delta \hat{h}_{i}^{o}+\left[\hat{h}_{i}-\Delta \hat{h}_{i}\right]
$$

where $\Delta \hat{h}_{i}$ is the standard molar enthalpy of formation gas $i(\mathrm{~J} / \mathrm{kmol})$.

The fuel's lower heating value (LHV) can be conveniently introduced into the energy balance represented by Equation 1 if it is assumed that the reactions of hydrocarbon, alcohol, and/or hydrogen fuel constituents are complete, as given by the following stoichiometric reaction:

$$
C_{x} H_{y} O_{z}+\left(x+\frac{y}{4}-\frac{z}{2}\right) \cdot \mathrm{O}_{2} \rightarrow x \cdot \mathrm{CO}_{2}+\frac{y}{2} \cdot \mathrm{H}_{2} \mathrm{O}
$$

Complete reactions are a reasonable assumption given the high operating temperatures of the SOFC stack and the afterburner, as confirmed by the emissions data given by Karakoussis et al. (2000). The LHV (J/kmol) of a fuel is expressed using the standard enthalpies of formation of the reactants and products (see Reynolds and Perkins [1977], for example),

$$
L H V_{\text {fuel }}=\frac{\Delta_{f} H_{\text {fuel }}^{o}+\Delta_{f} H_{\mathrm{O}_{2}}^{o}-\Delta_{f} H_{\mathrm{CO}_{2}}^{o}-\Delta_{f} H_{\mathrm{H}_{2} \mathrm{O}}^{o}}{\dot{N}_{\text {fuel }}}=\frac{\Delta_{f} H_{\text {fuel }}^{o}-\Delta_{f} H_{\mathrm{CO}_{2}}^{o}-\Delta_{f} H_{\mathrm{H}_{2} \mathrm{O}}^{o}}{\dot{N}_{\text {fuel }}} \text {, }
$$

where $\Delta_{f} H_{\text {fuel }}^{o}$ is the total flow rate of the standard enthalpy of formation of the fuel entering the FCPM control volume and $\Delta_{f} H_{\mathrm{CO}_{2}}^{o}$ and $\Delta_{f} H_{\mathrm{H}_{2} \mathrm{O}}^{o}$ are the total flow rates of the enthalpies of formation of the product gases created by the complete reaction of the fuel (all in W). $\dot{N}_{f u e l}$ is the molar flow rate of the fuel $(\mathrm{kmol} / \mathrm{s})$.

It is important to note that the $\Delta_{f} H_{\mathrm{H}_{2} \mathrm{O}}^{o}$ term in Equation 5 pertains only to the water vapor created through the electrochemical and combustion reaction of the fuel and oxygen. The water vapor that appears in the product gases as a result of liquid water supplied for steam reformation is not considered in this term. (Liquid water supplied for steam reformation produces a commensurate quantity of water vapor in the FCPM exhaust.) However, this water vapor is included in the $\dot{H}_{F C P M-c g}$ term in Equation 1, i.e.,

$$
\dot{H}_{F C P M-c g}=\dot{H}_{\text {products-of-reactions }}+\dot{H}_{\text {unreacted-fuel }+ \text { air }}+\dot{H}_{\mathrm{H}_{2} \mathrm{O}, \text { vap }},
$$

where $\dot{H}_{\text {products-of-reactions }}$ represents the total enthalpy flow rate of the products of the electrochemical and combustion reactions of the fuel and air $\left(\mathrm{H}_{2} \mathrm{O}\right.$ vapor and $\left.\mathrm{CO}_{2}\right) \cdot \dot{H}_{\text {unreacted-fuel }+ \text { air }}$ represents the total enthalpy flow rate of the unreacted fuel and air constituents $\left(\mathrm{N}_{2}, \mathrm{Ar}\right.$, excess $\mathrm{O}_{2}$, the $\mathrm{CO}_{2}$ constituent of the air and fuel supply, and the $\mathrm{H}_{2} \mathrm{O}$ vapor content of the air supply), and $\dot{H}_{\mathrm{H}_{2} \mathrm{O} \text {, vap }}$ represents the total enthalpy flow rate of the water vapor that is generated from the liquid water supply.

Using Equation 3, the latter term can be expressed by

$$
\dot{H}_{\mathrm{H}_{2} \mathrm{O}, \text { vap }}=\dot{N}_{\text {liq-water }} \cdot\left\{\Delta_{f} \hat{h}_{\mathrm{H}_{2} \mathrm{O}, \text { vap }}^{o}+\left[\hat{h}_{\mathrm{H}_{2} \mathrm{O}, \text { vap }}-\Delta_{f} \hat{h}_{\mathrm{H}_{2} \mathrm{O}, v a p}^{o}\right]\right\},
$$

where $\dot{N}_{\text {liq-water }}$ is the molar flow rate of liquid water (kmol/s) added for reformation purposes. 
Making use once again of Equation 3 and by both adding and subtracting the standard enthalpy of formation of water vapor, the $\dot{H}_{\text {liq-water }}$ term of Equation 1 can be represented by

$$
\begin{aligned}
\dot{H}_{\text {liq-water }} & =\dot{N}_{\text {liq-water }} \cdot\left\{\Delta_{f} \hat{h}_{\mathrm{H}_{2} \mathrm{O}, \text { liq }}^{o}+\left[\hat{h}-\Delta_{f} \hat{h}^{o}\right]_{\mathrm{H}_{2} \mathrm{O}, \text { liq }}-\Delta_{f} \hat{h}_{\mathrm{H}_{2} \mathrm{O}, \text { vap }}^{o}\right\}+\dot{N}_{\text {liq-water }} \cdot \Delta_{f} \hat{h}_{\mathrm{H}_{2} \mathrm{O}, \text { vap }} \\
& =\dot{N}_{\text {liq-water }}\left\{\left[\hat{h}-\Delta_{f} \hat{h}^{o}\right]_{\mathrm{H}_{2} \mathrm{O}, \text { liq }}-\Delta_{f} \hat{h}_{\mathrm{H}_{2} \mathrm{O}, f g}^{o}\right\}+\dot{N}_{\text {liq-water }} \cdot \Delta_{f} \hat{h}_{\mathrm{H}_{2} \mathrm{O}, \text { vap }}^{o},
\end{aligned}
$$

where $\Delta_{f} \hat{h}_{\mathrm{H}_{2} \mathrm{O}, f g}^{o}$ is the latent heat of vaporization of water at the standard state $(\mathrm{J} / \mathrm{kmol})$.

As is common in the literature (e.g., Bove et al. [2005b] and Dorer et al. [2005]) the FCPM's electrical efficiency is expressed relative to the fuel's LHV,

$$
\varepsilon_{e l}=\frac{P_{e l}}{\dot{N}_{f u e l} \cdot L H V_{f u e l}} .
$$

The energy balance represented by Equation 1 can be reformed by substituting in Equations 2, 3 , and 5 through 9 and rearranging. It can be shown that the standard enthalpy of formation of the unreacted fuel and air constituents appear on both sides of the equation (see $\dot{H}_{\text {air }}$ and $\dot{H}_{f u e l}$ in Equation 1 and $\dot{H}_{\text {unreacted-fuel +air }}$ in Equation 6). As well, the $\dot{N}_{\text {liq-water }} \cdot \Delta_{f} \hat{h}_{\mathrm{H}_{2} \mathrm{O} \text {, vap }}^{o}$ terms in Equations 7 and 8 cancel each other. Given this, it can be shown that the energy balance of the FCPM control volume can be represented as

$$
\begin{gathered}
\sum_{i}\left(\dot{N}_{i} \cdot\left[\hat{h}_{i}-\Delta_{f} \hat{h}_{i}^{o}\right]\right)_{f u e l}+\sum_{i}\left(\dot{N}_{i} \cdot\left[\hat{h}_{i}-\Delta_{f} \hat{h}_{i}^{o}\right]\right)_{a i r}+\dot{N}_{\text {liq-water }}\left\{\left[\hat{h}-\Delta \hat{h}^{o}\right]_{\mathrm{H}_{2} \mathrm{O}, l i q}-\Delta_{f} \hat{h}_{\mathrm{H}_{2} \mathrm{O}, f g}\right\} \\
\quad+P_{\text {el, anc-AC }}+\left(1-\varepsilon_{e l}\right) \cdot \dot{N}_{\text {fuel }} \cdot L H V_{\text {fuel }}=\sum_{i}\left(\dot{N}_{i} \cdot\left[\hat{h}_{i}-\Delta \hat{h}_{i}^{o}\right]\right)_{F C P M-c g}+q_{\text {skin-loss }}
\end{gathered} .
$$

As will be demonstrated in a later section, Equation 10 will be solved to yield the temperature of the product gases exiting the control volume and entering the auxiliary burner. A more computationally efficient approach could have been used to determine the temperature of these gases by simply calibrating this parameter to experimental data. However, as argued in the previous section, the more rigorous approach outlined here is used so that the impact of individual terms of the energy balance can be examined. For example, improving the thermal insulation of the FCPM could reduce the magnitude of the $q_{\text {skin-loss }}$ term. The impact of such a design change upon the temperature of the product gases could be determined through solution of Equation 10.

\section{Electrical Efficiency}

It is common to model the electrochemical behavior of fuel cell stacks by predicting cell voltages using the Nernst potential with empirical adjustments to account for activation, concentration, and ohmic losses (see, for example, Van herle et al. [2004] and Bove et al. [2005a]). Such an approach requires methods to establish the stack temperature and stack fuel utilization efficiency. This can only be accurately accomplished with an a priori knowledge of the system configuration, operational controls, and heat transfer characteristics between individual components (see Chan and Ding [2005], for example). 
In the IEA/ECBCS Annex 42 model, the fuel cell stack has been grouped with other components, such as the afterburner and heat exchangers, into the FCPM control volume. Such a treatment avoids the complications discussed above but also precludes an explicit treatment of the fuel cell's electrochemical behavior. Consequently, this model does not attempt to simulate the electrochemical processes occurring within the fuel cell but rather represents the electrochemical performance of the FCPM using a parametric relation between the electrical efficiency and the net electrical power output.

$$
\varepsilon_{e l}=\left[\varepsilon_{0}+\varepsilon_{1} \cdot P_{e l}+\varepsilon_{2} \cdot P_{e l}^{2}\right] \cdot\left[1-N_{\text {stops }} \cdot D\right]
$$

The $\left[1-N_{\text {stops }} \cdot D\right]$ term in Equation 11 represents the degradation of the FCPM's electrical efficiency as a result of stop-start cycling (electrical performance may degrade with time due to the thermal stresses induced during cooldown and warmup). $N_{\text {stops }}$ represents the number of times the SOFC-cogeneration system has been stopped and then restarted since its initiation, and $D$ is a user-input fixed value representing the fractional performance degradation associated with each cycle.

The approach represented by Equation 11 provides a great deal of flexibility for characterizing an FCPM's electrochemical performance. The $\varepsilon_{i}$ coefficients are supplied by the user. These coefficients could be determined by regressing measured data from a coherent system, as will be discussed later in this paper. Alternatively, empirical or analytical models could be used to predict polarization curves for a given cell design and additional models coupled to these to predict fuel utilization ratios and flow rates to produce a performance map that leads to the $\varepsilon_{i}$ coefficients. Another option is to employ detailed multidimensional mechanistic electrochemical, flow, and energy models based upon numerical discretization and solution schemes to predict FCPM performance over a range of operating points and then parameterize the results to yield the $\varepsilon_{i}$ coefficients. Examples of detailed models that could be used are those of Braun (2002) and Petruzzi et al. (2003).

It is worth noting that the three options listed above for establishing the $\varepsilon_{i}$ coefficients all rely heavily upon empirical data, either characterizing performance at the system, subsystem, or molecular level.

\section{Air Supply to FCPM}

The form of Equation 11 that represents the electrochemical performance of the FCPM includes an implicit relationship between the fuel and air supply rates. The model therefore requires an explicit relationship. Three alternative methods are provided for specifying this relationship. All three methods make use of an excess air ratio $(\lambda)$ that is based upon the stoichiometric reactions of the fuel constituents as given in Equation 4. Equation 4 is applied to each of the fuel constituents, and these results are combined with the flow rates of the fuel constituents and the user-specified molar fractions for the composition of air to establish the stoichiometric air flow rate, $\dot{N}_{\text {air }}^{s}$.

With the first method, the user specifies a fixed excess air ratio $(\lambda)$ and the airflow rate is determined as follows:

$$
\dot{N}_{\text {air }}=(1+\lambda) \cdot \dot{N}_{\text {air }}^{s}
$$

The user-specified molar fractions for the composition of air then lead to the solution of the flow rate of each air constituent $\left(\mathrm{N}_{2}, \mathrm{O}_{2}, \mathrm{H}_{2} \mathrm{O}\right.$, etc.) for the time step. 
Alternatively, the user may specify the excess air ratio as a parametric function of either the net electrical output or the fuel flow rate:

$$
\lambda=\frac{\left(a_{0}+a_{1} \cdot P_{e l}+a_{2} \cdot P_{e l}^{2}\right)}{\dot{N}_{\text {air }}^{s}}-1
$$

or

$$
\lambda=\frac{\left(a_{0}+a_{1} \cdot \dot{N}_{f u e l}+a_{2} \cdot \dot{N}_{f u e l}^{2}\right)}{\dot{N}_{\text {air }}^{s}}-1
$$

Next, the Shomate equation (NIST 2003) is used to evaluate the difference between the enthalpy of a gas and its standard enthalpy of formation as a polynomial function of its temperature (the temperature of the air entering the FCPM is determined through solution of the energy balance representing the blower's control volume),

$$
\hat{h}_{i}-\Delta_{f} \hat{h}_{i}^{o}=A \cdot\left(\frac{T}{1000}\right)+\frac{B}{2} \cdot\left(\frac{T}{1000}\right)^{2}+\frac{C}{3} \cdot\left(\frac{T}{1000}\right)^{3}+\frac{D}{4} \cdot\left(\frac{T}{1000}\right)^{4}-\frac{E}{\left(\frac{T}{1000}\right)}+F-H
$$

where the coefficients $A, B, C, D, E, F$, and $H$ are published in NIST's widely used Chemistry WebBook (NIST 2003). The evaluation of the aforementioned steps completes the determination of the $\sum_{i}\left(\dot{N}_{i} \cdot\left[\hat{h}_{i}-\Delta_{f} \hat{h}_{i}^{o}\right]\right)_{a i r}$ term of Equation 10.

\section{FCPM Product Gases}

As previously stated, it is assumed that the reactions of the fuel constituents are complete. Given this, the flow rate of $\mathrm{CO}_{2}$ and $\mathrm{H}_{2} \mathrm{O}$ that are produced by electrochemical oxidation (in the fuel cell stack) and combustion (in the afterburner) can be determined with Equation 4. When the flow rates of the nonreacting fuel and air constituents and of the water vapor generated as a result of liquid water supply are added to this, the composition and flow rate of the product gas stream is established. The Shomate equation (Equation 15) is then evaluated for each product gas constituent to establish the $\sum\left(\dot{N}_{i} \cdot\left[\hat{h}_{i}-\Delta_{f} \hat{h}_{i}^{o}\right]\right)_{F C P M-c g}$ term of Equation 10. Obviously, this evaluation requires that the temperature of the product gas stream be known. However, this is the quantity whose solution is sought. The method used to resolve this situation is treated later in the paper in the model implementation section.

\section{AUXILIARY BURNER AND HEAT RECOVERY}

The components that accomplish the SOFC-cogeneration device's thermal output are treated in this section.

\section{Auxiliary Burner}

Some SOFC-cogeneration devices may contain an integrated auxiliary burner for providing backup heating. The Sulzer-Hexis system, for example, contains an integrated auxiliary burner and a double-chamber heat exchanger (Diethelm 2004). The combustion gases from the FCPM are directed through one chamber of the heat exchanger, and the exhaust gases from the auxil- 
iary burner through the second chamber. The building's HVAC system circulates water through the heat exchanger to extract energy from both gas streams concurrently.

Although some SOFC-cogeneration systems may be configured with double-chamber heat exchangers, this model treats the combustion gases from the FCPM and the exhaust gases from the auxiliary burner as a single stream. It is felt that this modeling artifact will accurately represent the heat transfer from the enthalpy flow of the two gas streams while providing the model with flexibility for resolving various design configurations. Additionally, the control volume representing the auxiliary burner can be nullified in the case of designs where the auxiliary heating is either not present or accomplished elsewhere in the HVAC system (e.g., a burner within a water storage tank).

A schematic representation of the auxiliary burner control volume is illustrated in Figure 2. The state points shown in the figure are used in the development that follows. The control volume is represented by two sections to facilitate the description of its mathematical model: a burner section and a mixing section.

An energy balance can be written for the burner section that relates the total enthalpy flow rates of the supplied fuel and air and the exiting combustion gases, the heat losses from the burner, and the electrical power supplied to the burner's ancillary devices (all terms in units of W):

$$
\dot{H}_{f}+\dot{H}_{a}+P_{e l, a u x-a n c}=\dot{H}_{2}+q_{a u x-s k i n-l o s s}
$$

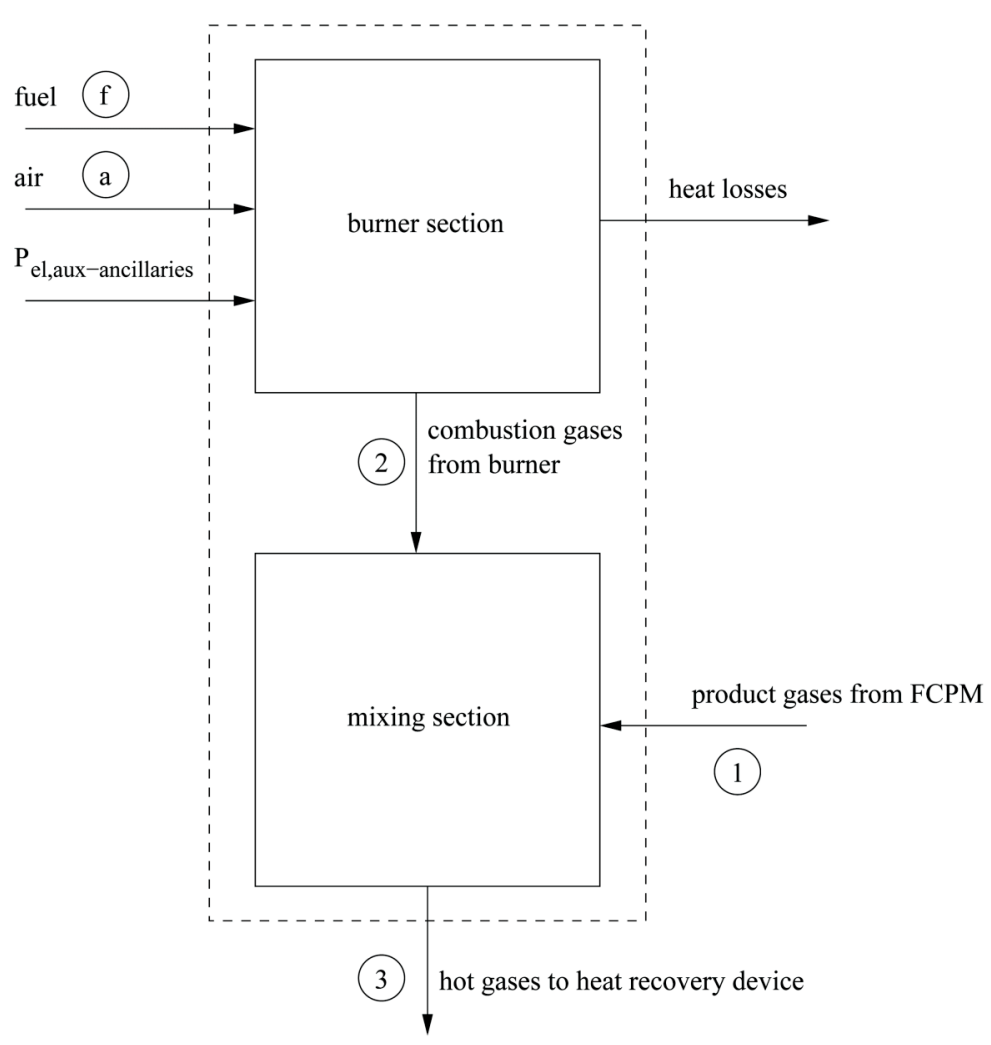

Figure 2. Auxiliary burner control volume. 
The flow rate of air introduced to the burner section (necessary for evaluating $\dot{H}_{a}$ ) is determined from the stoichiometric oxygen requirement (refer to Equation 4) and from a constant user-specified excess air ratio. The user can specify whether this air is drawn at the temperature of the room that contains the SOFC-cogeneration device or at the outdoor air temperature. Similarly, the user can specify whether the fuel is supplied at room or outdoor air temperature. It is assumed that the fuel mixture supplied to the auxiliary burner is the same as that supplied to the FCPM.

$P_{\text {el,aux-anc }}$ in Equation 16 is the electrical power (W) supplied to the auxiliary burner's ancillary devices (e.g., combustion air supply fan, controls, ignition system). It is assumed that all of the electrical power supplied to these ancillaries is added to the burner section. A first-order expression is used to evaluate this term,

$$
P_{e l, a u x-a n c}=x_{0}+x_{1} \cdot \dot{N}_{f},
$$

where $\dot{N}_{f}$ is the molar flow rate of the fuel mixture combusted in the auxiliary burner. This formulation assumes that the ancillary power draws of the auxiliary burner are proportional to the burner's fuel supply rate. (Note that $P_{\text {el,aux-anc }}$ is zero when the burner is inoperative.)

$q_{\text {aux }- \text { skin-loss }}$ in Equation 16 is the heat loss (W) from the burner section, which is the portion of the energy from the combustion of the fuel that does not leave the burner section in the gas stream (i.e., the $\dot{H}_{2}$ term). As shown in Figure 1, $q_{\text {aux-skin-loss }}$ can either be lost to the containing room or can be recovered to preheat the FCPM's air intake. It is assumed that this heat transfer is proportional to the temperature difference between the combustion gases exiting the burner section and the air in the room containing the SOFC-cogeneration device,

$$
q_{\text {aux-skin-loss }}=(U A)_{a u x} \cdot\left(T_{2}-T_{\text {room }}\right) \text {, }
$$

where $(U A)_{a u x}$ is a heat loss coefficient supplied by the user $(\mathrm{W} / \mathrm{K})$ that characterizes the convection and radiation from the skin of the auxiliary burner to the containing room, and $T_{\text {room }}$ is the air temperature of the room (e.g., basement, garage). It is important to note that $(U A)_{\text {aux }}$ is not a function of the temperature difference between the surface of the auxiliary burner and the room air but rather between the combustion gases and the room air. This is necessary, as the placement of the control volume that represents the auxiliary burner precludes the explicit solution of its surface temperature. $T_{2}$ was selected as an appropriate reference temperature for the skin losses since there should be a correlation between it and the surface temperature.

By assuming that the combustion of the fuel is complete, the LHV of the fuel can be introduced into the energy balance (refer to previous development for the FCPM). With this, Equation 16 can be represented by

$$
\begin{gathered}
\sum_{i}\left(\dot{N}_{i} \cdot\left[\hat{h}_{i}-\Delta \hat{h}_{i}^{o}\right]\right)_{f}+\sum_{i}\left(\dot{N}_{i} \cdot\left[\hat{h}_{i}-\Delta \hat{h}_{i}^{o}\right]\right)_{a}+P_{\text {el, aux-anc }}+\dot{N}_{f} \cdot L H V_{f} \\
=\sum_{i}\left(\dot{N}_{i} \cdot\left[\hat{h}_{i}-\Delta \hat{h}_{i}^{o}\right]\right)_{2}+q_{\text {aux-skin-loss }}
\end{gathered} .
$$

The enthalpy terms of Equation 19, $\sum_{i}\left(\dot{N}_{i} \cdot\left[\hat{h}_{i}-\Delta \hat{h}_{f}^{o}\right]\right)_{\text {aux }-f u e l}, \sum_{i}\left(\dot{N}_{i} \cdot\left[\hat{h}_{i}-\Delta \hat{h}_{i}^{o}\right]\right)_{a u x-a i r}$, and $\sum_{i}\left(\dot{N}_{i} \cdot\left[\hat{h}_{i}-\Delta_{f} \hat{h}_{i}^{o}\right]\right)_{a u x-c g}$ are evaluated using the Shomate equation and the methods elaborated for the treatment of the FCPM. 
The burner's capacity is specified by the user and is expressed either in heat output (W) or fuel input $(\mathrm{kmol} / \mathrm{s})$. It is assumed that the burner can fully modulate from a minimum (user-specified) output to full capacity and that its operating point is controlled by a signal originating elsewhere in the HVAC system, e.g., a water storage tank temperature or the temperature of water returned from space-heating radiators. Referring to Figure 2 and assuming that the mixing section is adiabatic, molar and energy balances can be written for the mixing section as follows:

$$
\begin{gathered}
\dot{N}_{1, i}+\dot{N}_{2, i}=\dot{N}_{3, i} \\
\sum_{i}\left(\dot{N}_{i} \cdot\left[\hat{h}_{i}-\Delta_{f} \hat{h}_{i}^{o}\right]\right)_{1}=\sum_{i}\left(\dot{N}_{i} \cdot\left[\hat{h}_{i}-\Delta_{f} \hat{h}_{i}^{o}\right]\right)_{2}+\sum_{i}\left(\dot{N}_{i} \cdot\left[\hat{h}_{i}-\Delta_{f} \hat{h}_{i}^{o}\right]\right)_{3}
\end{gathered}
$$

where Equation 20 applies for each constituent gas $i$, e.g., $\mathrm{CO}_{2}, \mathrm{H}_{2} \mathrm{O}, \mathrm{N}_{2}$.

The three terms in Equation 21 represent the enthalpy flow rates relative to the standard state (W) of the gases exiting the FCPM control volume and the burner section and of the gases exiting the auxiliary burner control volume and entering the gas side of the heat recovery device.

As previously stated, the auxiliary heater control volume can be easily nullified in the case of modelling SOFC-cogeneration systems where the auxiliary heating is either not present or accomplished elsewhere in the HVAC system. In this case, Equations 16 through 21 will reduce to a form that represents a flow-through control volume in which the flow rate and enthalpy of the exiting gases are equal to the entering values.

\section{Exhaust Gas to Water Heat Exchanger}

A schematic representation of the control volume encapsulating the device that transfers heat from the auxiliary burner (or FCPM) control volume exhaust gases to the water loop connected to the building's HVAC system is shown in Figure 3. The state points shown in the figure are used in the development that follows.

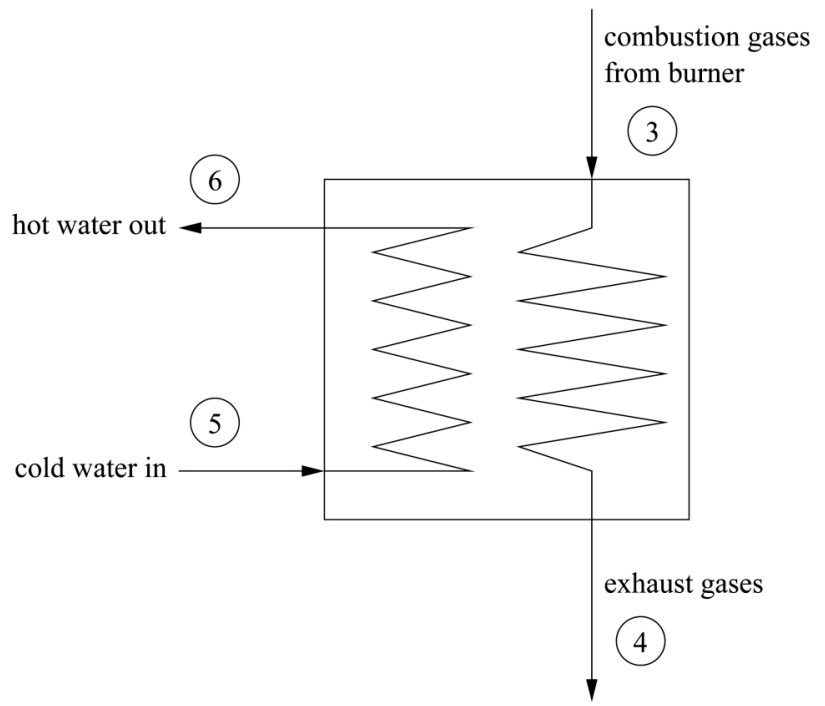

Figure 3. Heat exchanger control volume. 
The heat transfer from the hot gases to the water is characterized with the log mean temperature difference (LMTD) method for counterflow heat exchangers,

$$
q_{H X}=(U A)_{e f f} \cdot \frac{\left(T_{3}-T_{6}\right)-\left(T_{4}-T_{5}\right)}{\ln \left(\frac{T_{3}-T_{6}}{T_{4}-T_{5}}\right)},
$$

where $T_{4}$ is the temperature of the cooled gases that are exhausted to the ambient and $T_{6}$ is the temperature of the warmed water exiting the heat exchanger; $(U A)_{\text {eff }}$ is the effective product of the heat transfer coefficient and area $(\mathrm{W} / \mathrm{K})$.

If it is assumed that heat loss from the heat exchanger to the ambient is negligible and that the heat capacity of each fluid stream remains constant through the heat exchanger, then the following energy balance can be written for the heat transfer between the fluid streams:

$$
q_{H X}=\left(\dot{N}_{P_{P}}\right)_{3} \cdot\left(T_{3}-T_{4}\right)=\left(\dot{N}_{c_{P}}\right)_{5} \cdot\left(T_{6}-T_{5}\right)
$$

Equation 23 can be rearranged to express the outlet water temperature as a function of the water inlet temperature and the gas temperatures:

$$
T_{6}=T_{5}+\frac{\left(\dot{N} \hat{c}_{P}\right)_{3}}{\left(\dot{N} \hat{c}_{P}\right)_{5}} \cdot\left(T_{3}-T_{4}\right)
$$

By substituting Equation 24 into the numerator of Equation 22 and by replacing $q_{H X}$ with $\left(\dot{N} \hat{c}_{P}\right)_{3} \cdot\left(T_{3}-T_{4}\right)$, it can be shown that

$$
\ln \left(\frac{T_{3}-T_{6}}{T_{4}-T_{5}}\right)=\frac{(U A)_{e f f}}{\left(\dot{N} \hat{c}_{P}\right)_{3}} \cdot\left[1-\frac{\left(\dot{N} \hat{c}_{P}\right)_{3}}{\left(\dot{N} \hat{c}_{P}\right)_{5}}\right]
$$

By taking the exponential of each side of Equation 25, substituting in Equation 24, and rearranging, the gas outlet temperature can be expressed as a function of gas and water inlet temperatures:

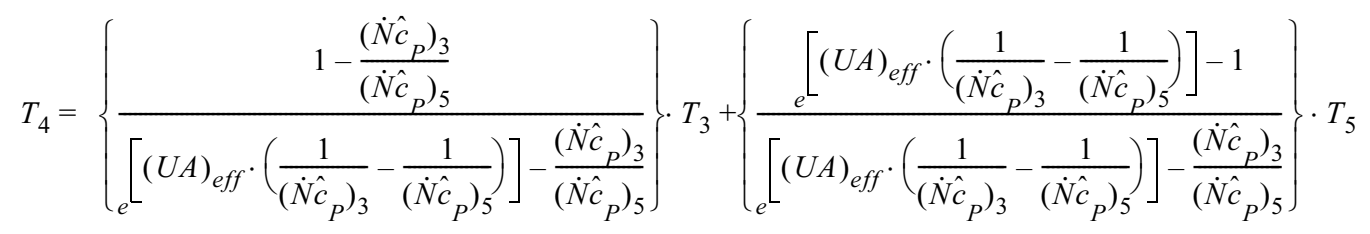

With the LMTD approach, the effective product of the heat transfer coefficient and area must be evaluated at each time step of the simulation. Two optional methods are provided for evaluat-

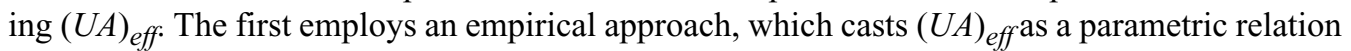
with the water and product gas flow rates:

$$
(U A)_{e f f}=h x_{s, 0}+h x_{s, 1} \cdot \dot{N}_{5}+h x_{s, 2} \cdot \dot{N}_{5}^{2}+h x_{s, 3} \cdot \dot{N}_{3}+h x_{s, 4} \cdot \dot{N}_{3}^{2}
$$


This method can be particularly useful when empirical data are available from the testing of a specific heat exchange device over a range of water inlet and product gas temperatures and flow rates. Such experimental data can be easily regressed to provide the $h x_{s, i}$ coefficients. It is worth noting that the empirical form of Equation 27 compensates for some of the assumptions inherent to the LMTD method, namely: that heat loss from the heat exchanger is not considered in Equation 23, that perfect counterflow conditions prevail, and that the fluid heat capacities are constant throughout the heat exchanger.

With the second method $(U A)_{\text {eff }}$ is cast in an idealized form based upon more fundamental heat transfer processes,

$$
(U A)_{e f f}=\left[\frac{1}{\left(h^{0} A\right)_{\text {gas }}\left(\frac{\dot{N}_{3}}{\dot{N}_{3}^{0}}\right)^{n}}+\frac{1}{\left(h^{0} A\right)_{\text {water }}\left(\frac{\dot{N}_{5}}{\dot{N}_{5}^{0}}\right)^{m}}+F_{H X}\right]
$$

where $h_{j}^{0}$ is the coefficient for the heat transfer from the heat exchanger surface to the air or gas stream at the nominal flow rate $\dot{N}_{j}^{0}$. These empirical constants, as well as the empirical constants $n$ and $m$, are supplied by the user. (Theoretical considerations can be used to establish the values of $n$ and $m$ as a function of fluid type, temperatures, and nature of flow. Conventional values are on the order of 0.5.) The user also supplies reference heat exchanger areas $A_{j}$ and the empirical constant $F_{H X}$. The latter represents the fouling of the heat exchanger and the heat transfer resistance of the surfaces and compensates for the errors inherent in the assumptions of Equation 28 (e.g., that the wall temperatures of the heat exchanger are uniform) and those of the LMTD method.

To facilitate the analysis of hypothetical systems where the performance characteristics of the heat transfer device are unknown, the user is given the option of supplying a fixed heat exchanger effectiveness $\left(\varepsilon_{H X}\right)$. At each time step of the simulation, this is used to calculate the heat recovery based upon the approach temperature, which is the temperature difference between the entering gas and water streams,

$$
q_{H X}=\varepsilon_{H X} \cdot\left(\dot{N}_{\hat{c}}\right)_{\text {min }} \cdot\left(T_{3}-T_{5}\right),
$$

where $\left(\dot{N} \hat{c}_{P}\right)_{\text {min }}$ is the minimum value of $\left(\dot{N} \hat{c}_{P}\right)_{3}$ and $\left(\dot{N} \hat{c}_{P}\right)_{5}$ for the current time step. In the case of heat exchangers that are capable of condensing water from the exhaust gas stream, an additional term is added to Equation 22 to account for the augmentation in heat transfer due to condensation,

$$
q_{H X}=q_{\text {sensible }}+q_{\text {latent }}=(U A)_{\text {eff }} \cdot \frac{\left(T_{3}-T_{6}\right)-\left(T_{4}-T_{5}\right)}{\ln \left(\frac{T_{3}-T_{6}}{T_{4}-T_{5}}\right)}+\dot{N}_{\mathrm{H}_{2} \mathrm{O}-\text { cond }} \cdot \hat{h}_{\mathrm{H}_{2} \mathrm{O}, f g}
$$

where $\dot{N}_{\mathrm{H}_{2} \mathrm{O} \text {-cond }}$ is the rate of condensation of water from the gas stream $(\mathrm{kmol} / \mathrm{s})$ and $\hat{h}_{\mathrm{H}_{2} \mathrm{O}, f g}$ is the molar heat of vaporization of water $(\mathrm{J} / \mathrm{kmol})$.

The sensible component of the heat exchange is determined as previously described (see Equations 23 through 27). The rate of condensation is expressed in a parametric form that facilitates the determination of its coefficients from empirical data. The functional form of this parametric equation was established by recognizing that, for a given heat exchanger, the rate of condensation will be primarily influenced by the concentration of water vapor in the gas stream and by the difference between the heat exchanger's temperature and the dew point of the gas, 


$$
\dot{N}_{\mathrm{H}_{2} \mathrm{O} \text {-cond }}=\left(T_{\text {cond-threshold }}-T_{5}\right) \cdot\left[h x_{l, 1} \cdot\left(\frac{\dot{N}_{\mathrm{H}_{2} \mathrm{O}}}{\dot{N}_{3}}\right)+h x_{l, 2} \cdot\left(\frac{\dot{N}_{\mathrm{H}_{2} \mathrm{O}}}{\dot{N}_{3}}\right)^{2}\right] .
$$

$\dot{N}_{\mathrm{H}_{2} \mathrm{O}}$ in Equation 31 is the molar flow rate of water vapor in the gas stream entering the heat exchanger and $\dot{N}_{3}$ is the molar flow rate of all gases.

$T_{\text {cond-threshold }}$ is a user-specified fixed value that represents the threshold of the water-inlet temperature above which condensation will not occur. When $T_{5}$ is below $T_{\text {cond-threshold }}$, the condensation rate will be determined with Equation 31. And when $T_{5}$ is above $T_{\text {cond-threshold }}$, it is assumed that no condensation occurs. The model relies upon the user specifying $T_{\text {cond-threshold }}$ for the heat exchange device rather than attempting to calculate a dew point for the gas stream since this parameter is a function of heat exchanger design and gas pressure. The $h x_{l, i}$ coefficients and $T_{\text {cond-threshold }}$ in Equation 31 can be derived by testing a specific heat exchange device over a range of water inlet and gas inlet temperatures and by measuring the heat transfer and by measuring (or calculating based upon the measured fuel flow rate and air inlet flow rate) the gas composition.

\section{MODEL IMPLEMENTATION}

The previously described model was implemented into a number of building simulation programs as part of the IEA/ECBCS Annex 42 collaborative work. This section treats some of the issues related to model implementation by illustrating its incorporation into the explicit plant domain of the ESP-r program (ESRU 2002).

\section{ESP-r's Explicit Plant Modeling Domain}

ESP-r's explicit plant modeling domain is based upon a component-level approach whereby users assemble components into a coherent HVAC system. Data must be provided to define each component (e.g., a boiler) and the arrangement of the components. Users must also specify how components are controlled, indicating what variables are sensed (e.g., air temperature in a room), and how components are actuated (e.g., water flow through a coil) in response to the sensor signals. Each component in the HVAC network is represented by one or more control volumes and each control volume is characterized by mathematical models that describe the control volume's energy and mass exchanges with connected components and the environment. The energy balances are expressed in the following form:

$$
\left(M c_{p}\right) \frac{\partial T}{\partial t}=\sum_{i=1}^{i=n} q_{i}
$$

where $M$ is the mass of the control volume, $c_{p}$ its heat capacity, $T$ its temperature, $t$ is time, and $q_{i}$ is an energy flow into the control volume.

The left side of this equation represents the rate of change of energy storage in the control volume. The right side represents all the energy flows that affect the control volume's thermal state. Depending upon the component under consideration, these energy flows might be a convective flux from the skin of the component to the containing room, an energy release due to combustion, or advection resulting from water or airflow through the control volume. These energy flows can be expressed with simple or complex models and can be based upon first-principle or empirical approaches, as the situation dictates. Similar equations are written to represent the water and air mass balances on each control volume.

Writing energy and mass balances for each control volume leads to the formation of three matrices of equations that describe the HVAC plant network's thermal and mass flow state. A 
direct solution approach is used to solve these three matrices. As the equation set is highly nonlinear, iteration is used to reform and resolve the matrices until convergence is achieved for the given time step (refer to Hensen [1991] for details). The results of the solved plant state for a given time step are communicated to the modeling domains that treat the thermal state of the building fabric, the electrical systems, etc., and then the process elaborated above is repeated for each subsequent time step of the simulation. The interested reader is referred to Clarke (2001) for further details on ESP-r's theoretical basis.

\section{Linearization of Enthalpy Terms}

As outlined above, ESP-r plant domain solver operates on nodal temperatures. However, in the energy balance representing the FCPM the temperature of the control volume is only implicit. Referring to Equations 10 and 15, the enthalpy of the hot product gases exiting the control volume is a function of the temperature whose solution is sought $\left(T_{F C P M-c g}\right)$.

$$
\sum_{i}\left(\dot{N}_{i} \cdot\left[\hat{h}_{i}-\Delta_{f} \hat{h}_{i}^{o}\right]\right)_{F C P M-c g}=\sum_{i}\left(\dot{N}_{i} \cdot\left[A \cdot\left(\frac{T}{1000}\right)+\frac{B}{2} \cdot\left(\frac{T}{1000}\right)^{2}+\frac{C}{3} \cdot\left(\frac{T}{1000}\right)^{3}+\frac{D}{4} \cdot\left(\frac{T}{1000}\right)^{4}-E \cdot\left(\frac{T}{1000}\right)+F-H\right]\right)_{F C P M-c g}
$$

Consequently, for implementation into ESP-r, the energy balance must be linearized with respect to $T_{F C P M-c g}$. This starts with the definition of the heat capacity of a gas.

$$
\hat{c}_{P}=\left.\frac{\partial \hat{h}}{\partial T}\right|_{P}
$$

The enthalpy difference between a gas at any two states can be determined through integration of Equation 34. $\hat{c}_{p}$ can be treated as constant if the two state points are sufficiently close for its variation to be negligible. In this context, the two state points are taken to be the solutions at two successive solver iterations within the time step $(j-1$ and $j$ ). This leads to the following:

$$
\hat{h}_{i}^{j}-\hat{h}_{i}^{j-1}=\hat{c}_{P_{i}} \cdot\left(T^{j}-T^{j-1}\right)
$$

With this, the enthalpy term represented by Equation 33 can be expressed as

$$
\sum_{i}\left(\dot{N}_{i} \cdot\left[\hat{h}_{i}-\Delta_{f} \hat{h}_{i}^{o}\right]\right)_{F C P M-c g}^{j}=\sum_{i}\left(\dot{N}_{i} \cdot\left[\hat{h}_{i}-\Delta_{f} \hat{h}_{i}^{o}\right]\right)_{F C P M-c g}^{j-1}+\sum_{i}\left(\dot{N}_{i} \cdot c_{P_{i}}\right)^{j-1} \cdot\left(T^{j}-T^{j-1}\right)
$$

Note that $\left[\Delta_{f} \hat{h}_{i}^{o}\right]^{j}=\left[\Delta_{f} \hat{h}_{i}^{o}\right]^{j-1}$ since this is the standard enthalpy of formation.

The energy balance of Equation 10 is rearranged as follows:

$$
\begin{aligned}
\sum_{i}\left(\dot{N}_{i} \cdot\left[\hat{h}_{i}-\Delta_{f} \hat{h}_{i}^{o}\right]\right)_{F C P M-c g}^{j} & = \\
\sum_{i}\left(\dot{N}_{i} \cdot\left[\hat{h}_{i}-\Delta_{f} \hat{h}_{i}^{o}\right]\right)_{f u e l} & +\sum_{i}\left(\dot{N}_{i} \cdot\left[\hat{h}_{i}-\Delta_{f} \hat{h}_{i}^{o}\right]\right)_{\text {air }}+\dot{N}_{\text {liq-water }}\left\{\left[\hat{h}-\Delta_{f} \hat{h}^{o}\right]_{\mathrm{H}_{2} \mathrm{O}, \text { liq }}-\Delta_{f} \hat{h}_{\mathrm{H}_{2} \mathrm{O}, f g}\right\} \\
& +P_{\text {el, anc-AC }}+\left(1-\varepsilon_{\text {el }}\right) \cdot \dot{N}_{\text {fuel }} \cdot L H V_{\text {fuel }}-q_{\text {skin-loss }}
\end{aligned}
$$


Substituting Equation 36 into Equation 37 leads to the following form of the energy balance for the FCPM in terms of the unknown temperature, a form suitable for ESP-r's plant matrix solver:

$$
\begin{gathered}
T_{F C P M-c g}^{j}=T_{F C P M-c g}^{j-1}+\frac{1}{\sum_{i}\left(\dot{N}_{i} \cdot c_{P}\right)^{j-1}} \cdot \\
\left(\sum_{i}\left(\dot{N}_{i} \cdot\left[\hat{h}_{i}-\Delta_{f} \hat{h}_{i}^{o}\right]\right)_{f u e l}+\sum_{i}\left(\dot{N}_{i} \cdot\left[\hat{h}_{i}-\Delta \hat{h}_{i}^{o}\right]\right)_{\text {air }}+\dot{N}_{\text {liq-water }}\left\{\left[\hat{h}-\Delta \hat{h}_{f}^{o}\right]_{\mathrm{H}_{2} \mathrm{O}, l i q}-\Delta_{f} \hat{h}_{\mathrm{H}_{2} \mathrm{O}, f g}^{o}\right\}\right. \\
\left.+P_{\text {el,anc-AC }}+\left(1-\varepsilon_{e l}\right) \cdot \dot{N}_{f u e l} \cdot L H V_{f u e l}-q_{\text {skin-loss }}-\sum_{i}\left(\dot{N}_{i} \cdot\left[\hat{h}_{i}-\Delta_{f} \hat{h}_{i}^{o}\right]\right)_{F C P M-c g}^{j-1}\right)
\end{gathered}
$$

\section{MODEL DEMONSTRATION}

Energy balances for each of the SOFC-cogeneration device's nine control volumes were formed in ESP-r's explicit plant modeling domain using the methods previously described. Where necessary, the energy balances were linearized with respect to temperature using the technique outlined above. With this, the IEA/ECBCS Annex 42 SOFC-cogeneration model can be coupled to ESP-r's models of associated HVAC plant components, such as hot-water storage, peak-load boilers and heaters, pumps that circulate hot or cold water to hydronic heaters located in the rooms or to air-handling units, fans that circulate conditioned air to the rooms, and heat exchangers. In turn, these models, representing the building's coherent HVAC and electrical production systems, can be coupled to models that predict the building's thermal and electrical demands.

This section demonstrates the operation of this modeling capability by simulating the performance of a hypothetical SOFC-cogeneration device that is coupled to the space-heating system of a house. The intent is not to examine the performance of actual systems but rather to demonstrate the new modeling capabilities and to illustrate the types of analyses that can be conducted.

As illustrated in Figure 4, the system is configured such that the SOFC-cogeneration's thermal output is used to offset the space-heating needs of the house. A hot water tank is used to buffer between the SOFC-cogeneration device's thermal output and the house's space-heating requirements. This tank is sized at $500 \mathrm{~L}$ for the simulations reported here. A pump circulates water from the SOFC-cogeneration device's heat recovery device to a heat exchanger to add the thermal output to the tank. Similarly, a pump circulates water from the tank to a fan-coil unit that distributes warm air to heat the house. For the purposes of demonstrating the new model, these heat exchangers are modeled with a $100 \%$ effectiveness.

A supplemental burner is controlled to heat the tank when the SOFC-cogeneration system's thermal output is insufficient to maintain the tank's temperature. The tank's burner cycles on when the tank temperature drops below its lower setpoint $\left(50^{\circ} \mathrm{C}\right.$ in this case) and cycles off once the tank temperature rises above its upper setpoint $\left(60^{\circ} \mathrm{C}\right.$ in this case). A safety device is modeled by extracting hot water from the tank when its temperature rises above a safety limit $\left(85^{\circ} \mathrm{C}\right.$ in this case). When the SOFC-cogeneration device's thermal output exceeds the house's space-heating requirements and exceeds the tank's ability to store this energy, this safety device essentially dumps the excess thermal output.

Model inputs for the nine control volumes describing the SOFC-cogeneration device were assigned. Realistic data were selected for the purposes of demonstrating the mode; however, it must be stressed that these data correspond to a hypothetical system. (Calibrating the model's inputs is treated in a subsequent section.) Representative data were also selected to characterize 


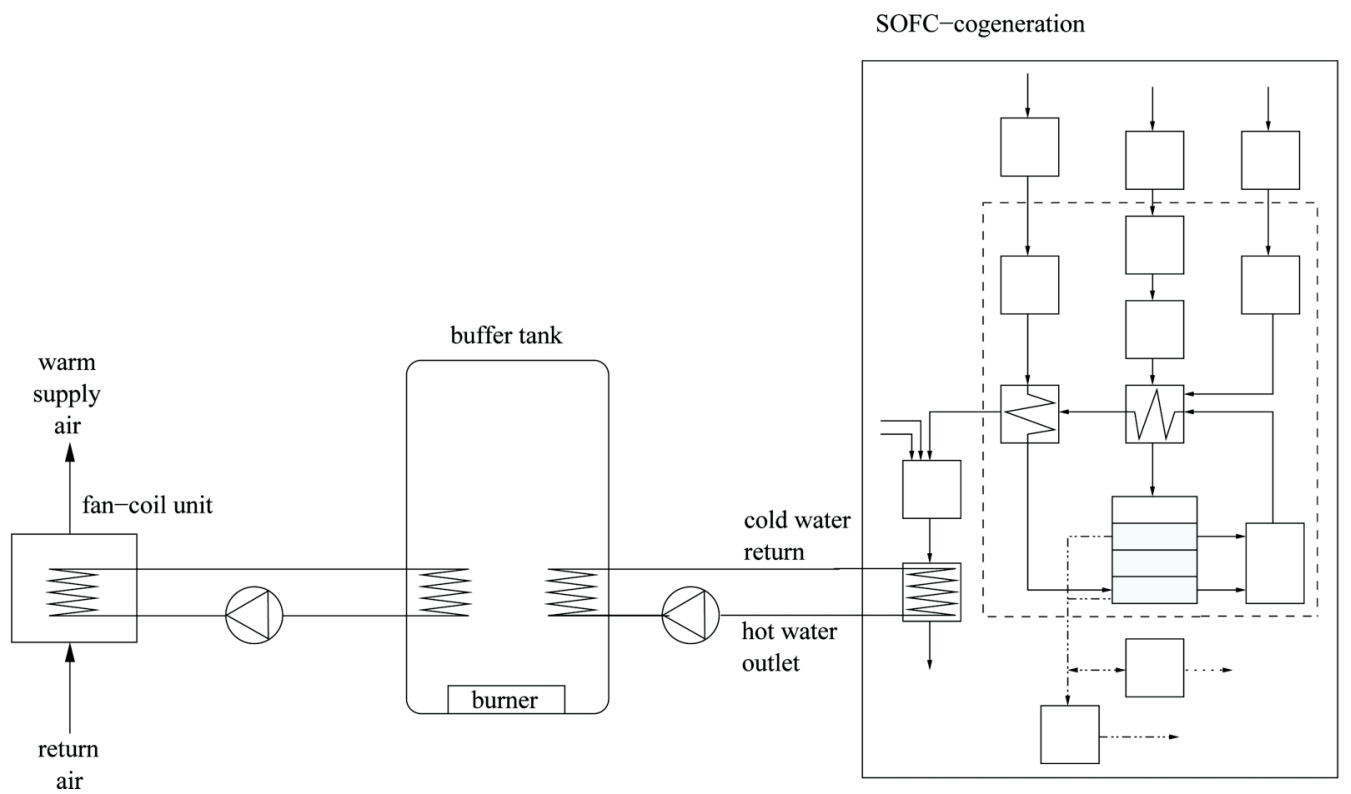

Figure 4. Schematic of HVAC system used to demonstrate model.

the other HVAC plant components (e.g., fan coil, pumps). The house model itself is representative of modern residential construction and the electrical usage pattern (e.g., appliances and lighting) is typical of a family of four with an average demand of about $1400 \mathrm{~W}$. Montréal (Canada) weather data were used in the simulations, which were conducted using a five-minute time step.

\section{Example Electrical Results}

In the first simulation, the model was configured such that the SOFC-cogeneration device produced a constant electrical output of $1400 \mathrm{~W}$, the average demand for the house. Figure 5 shows the electrical demand and the SOFC-cogeneration device's electrical production for a typical day in February. The electricity imported and exported to the grid in order to balance the supply and demand is also illustrated. Over a one-week period in February, the total electrical consumption and production were 237 and $235 \mathrm{kWh}$, respectively. The minimum and maximum electrical demands were $300 \mathrm{~W}$ and $5.4 \mathrm{~kW}$, and $46 \mathrm{kWh}$ of electricity were imported from the grid while $44 \mathrm{kWh}$ were exported. The peak rate of importation was $4.0 \mathrm{~kW}$, while the peak rate of exportation was $1.1 \mathrm{~kW}$.

In the second simulation, the SOFC-cogeneration device was configured to follow the electrical demand pattern. The model includes inputs that limit how quickly the device's electrical output can respond to changes in demand. This mimics the behavior of internal control systems that manage the device's transient response to avoid excessive thermal stressing. In this case, the device's maximum increase or decrease in electrical power output was constrained to $0.27 \mathrm{~W} / \mathrm{s} \approx 1 \mathrm{~kW} / \mathrm{h}$ (the model permits the use of different values for increasing and decreasing output). It was assumed that the SOFC-cogeneration device's electrical output could modulate from zero to $5 \mathrm{~kW}$. Figure 6 again illustrates the demand, production, and grid interaction for the same day in February. This figure clearly illustrates that the device follows the general trend of the electrical demand pattern but is unable to ramp up or down sufficiently quickly to fully bal- 


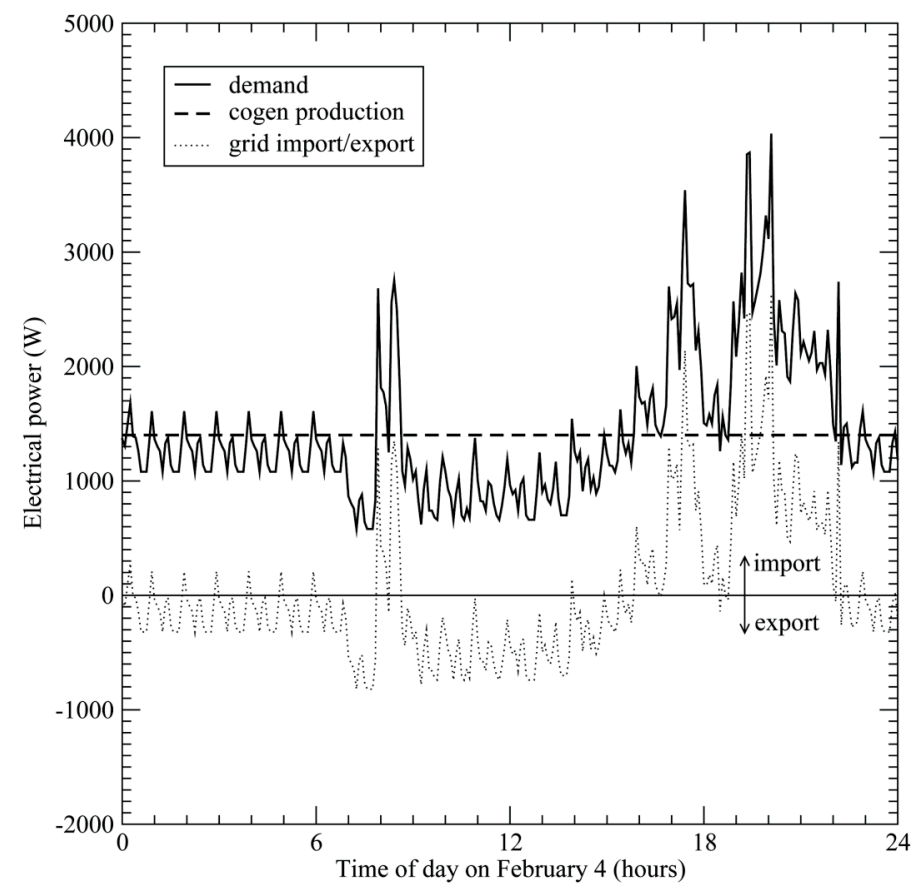

Figure 5. Constant electrical production.

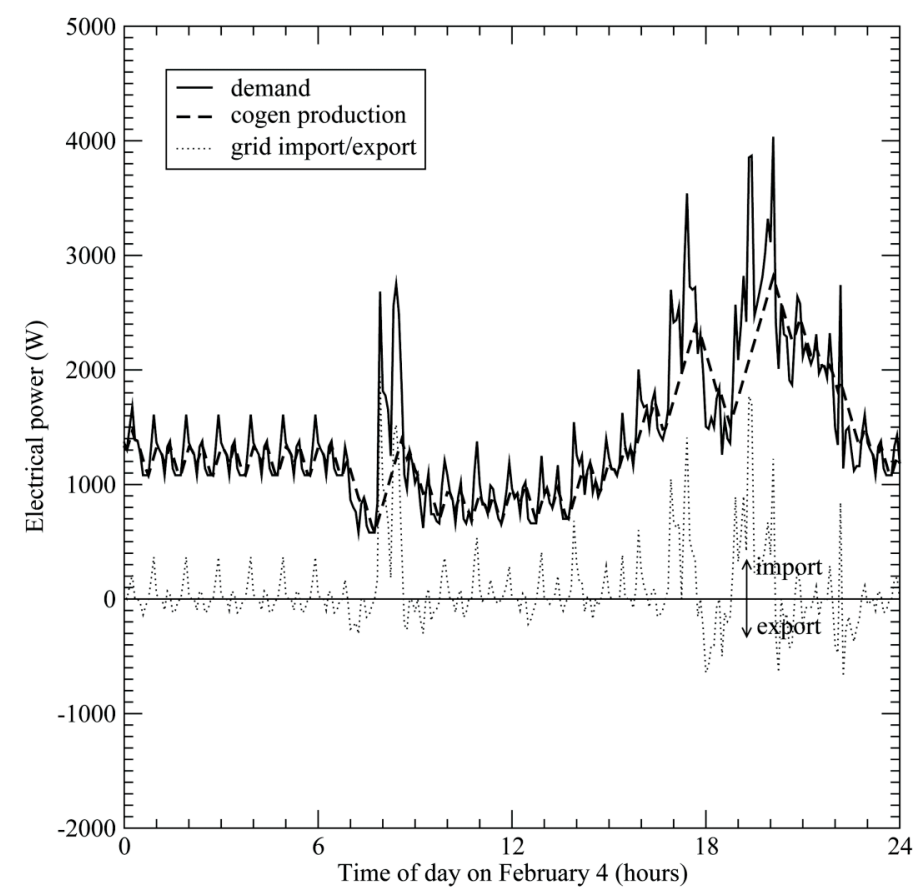

Figure 6. Electric load following $1 \mathrm{~kW} / \mathrm{h}$ response rate. 
ance the production with the demand. The SOFC-cogeneration device produces less electrical energy in this operating scenario, $220 \mathrm{kWh}$, or $6 \%$ less than the previous case. Although the grid is relied upon less often to meet spikes in loads and to export excess power production $(30 \mathrm{kWh}$ of importation, $35 \%$ less than before; $12 \mathrm{kWh}$ of exportation, $73 \%$ less than before), the peak rate of import $(3.8 \mathrm{~kW})$ and export $(1.2 \mathrm{~kW})$ are relatively unchanged.

Grid reliance could be reduced with a more rapidly responding SOFC-cogeneration device. To examine this sensitivity, another simulation was conducted with electric load following, but this time the device's output was able to respond twice as quickly- $0.54 \mathrm{~W} / \mathrm{s} \approx 2 \mathrm{~kW} / \mathrm{h}$. These results are shown in Figure 7. A faster-responding device does further reduce the energy drawn from $(18 \mathrm{kWh}, 40 \%$ lower than the previous run) or transferred to ( $8 \mathrm{kWh}, 33 \%$ lower $)$ the grid, but it relies just as much for peak import $(3.6 \mathrm{~kW})$ and export $(1.4 \mathrm{~kW})$.

\section{Example Thermal Results}

The thermal conditions within the tank that buffer between the SOFC-cogeneration device's thermal output and the house's space-heating requirements are plotted in Figure 8 for the month of October for the case where the device produces a constant $1400 \mathrm{~W}$ of electricity. As can be seen, there is a near-constant addition of heat to the tank from the SOFC-cogeneration device. (Although the SOFC-cogeneration device produces a constant $1400 \mathrm{~W}$ of electricity, its thermal output is not constant because the cold water inlet to the heat recovery device varies with the thermal state of the tank; refer to Equation 29).

Due to warm weather, there are only sporadic draws from the tank to satisfy space-heating requirements during the first 19 days of October. During this time the energy added to the tank by the SOFC-cogeneration device exceeds the energy removed to supply space heating. As a consequence, the tank frequently overheats to the $85^{\circ} \mathrm{C}$ safety limit and heat is dumped from the tank. The tank cools considerably from October 19 to 21 in response to increased space-heating draws. And from October 21 through 31 it can be seen that the burner cycles on frequently to supplement the SOFC-cogeneration system's thermal output to meet the house's space-heating requirements. It is worth noting that although the space-heating draws are less frequent from October 1 through 19, they are greater in magnitude. This is a result of the control strategy employed in the simulation. When there is a call for heat, water is circulated from the tank to the fan-coil unit for the duration of the simulation time step (five minutes in this case). Since the tank temperature is hotter during this part of the month, the corresponding heat transfer from the tank is greater.

When integrated over the month, the SOFC-cogeneration device adds 4.4 GJ of thermal energy to the tank, whereas the space-heating draw removes only 3.3 GJ. Consequently, much of the thermal output from the SOFC-cogeneration device must be rejected. The temporal mismatch between thermal production and demand further exacerbates this situation. The burner must be fired in the latter half of the month since the excess thermal energy produced in the former half of the month is not stored over this time scale.

This example clearly illustrates opportunities for using the new modeling capability to examine strategies for maximizing the SOFC-cogeneration's thermal output. For example, the model could easily be configured to determine the potential benefits of alternate buffer tank capacities, heat exchanger performance characteristics, and burner and heat dump control setpoints. Additionally, it could be used to examine alternative control strategies (e.g., thermal load following) that might minimize the operating cost of the system or maximize the profit of producing electricity while satisfying the house's thermal demands by optimizing the use of the buffering tank that allows a certain decoupling between electricity and thermal demands (e.g., Weber et al. [2005]). 


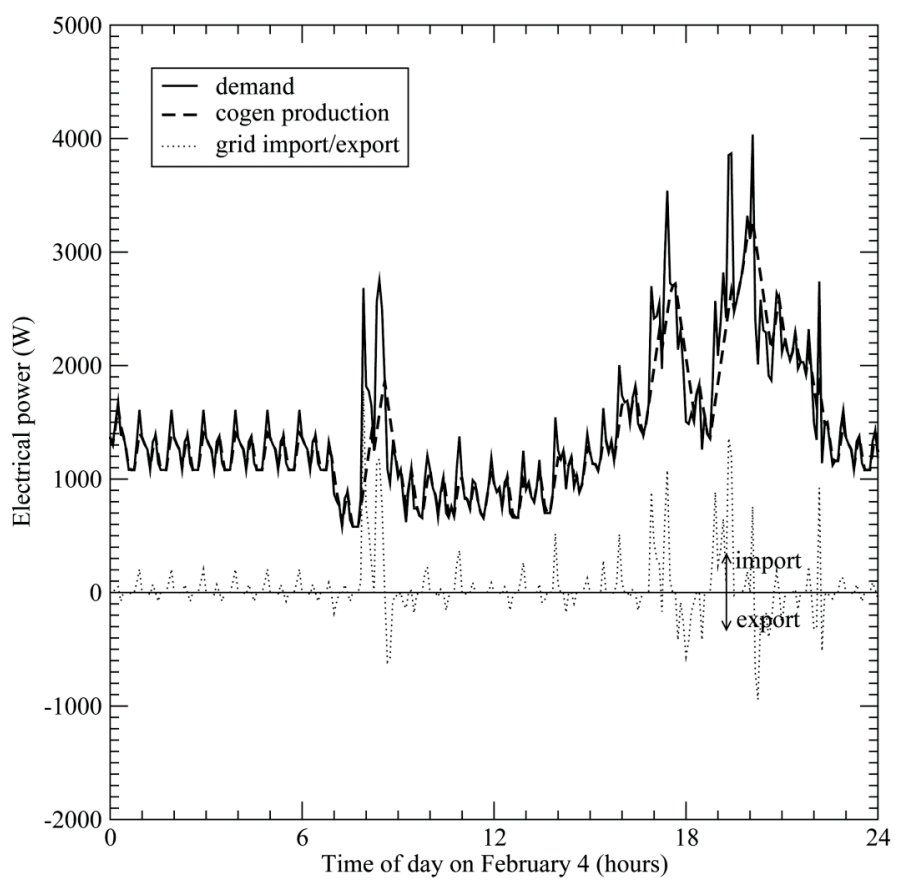

Figure 7. Electric load following $2 \mathrm{~kW} / \mathrm{h}$ response rate.

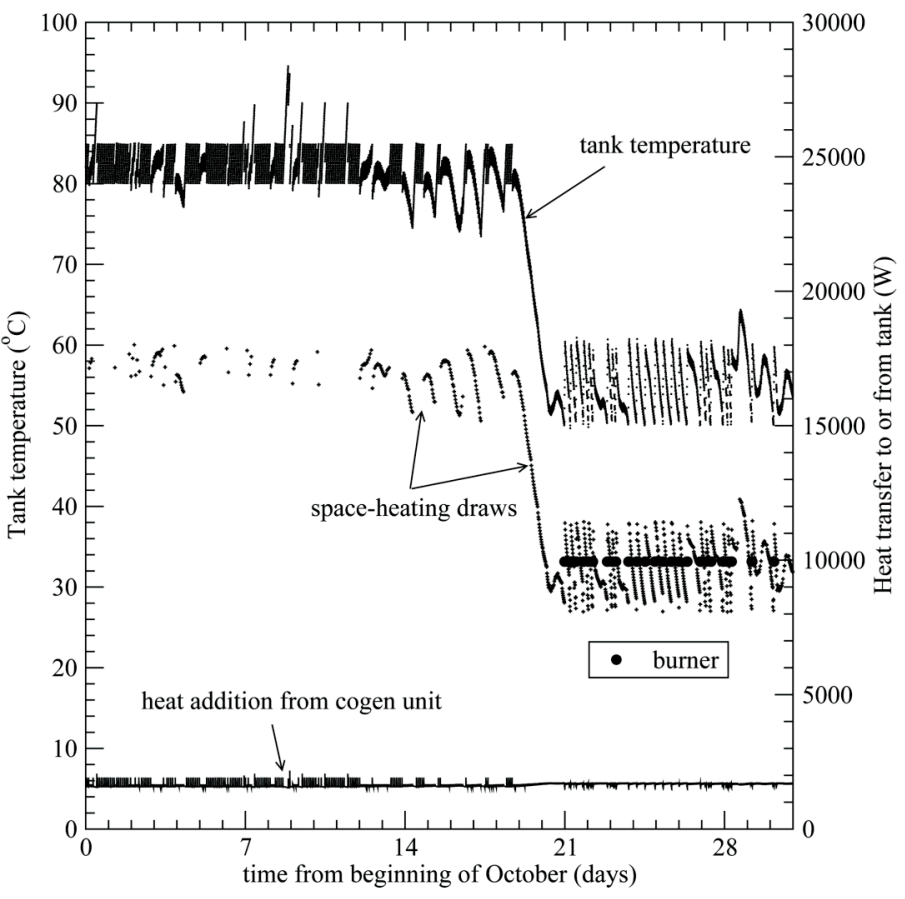

Figure 8. Thermal conditions within buffering tank. 


\section{MODEL VALIDATION AND CALIBRATION}

\section{Calibration}

The previous section demonstrated the use of the SOFC-cogeneration model using hypothetical data. In order to model representative systems that are under development, it is necessary to calibrate the model by deriving inputs for the various terms of the energy balances that characterize the electrical and thermal performance.

The heat recovery device, for example, can be characterized with Equation 27, which expresses $(U A)_{e f f}$ as a parametric function of the flow rates of water and product gas through the heat exchanger. A series of tests are being conducted to examine the performance of the heat exchanger of SOFC-cogeneration devices over a wide range of operating conditions:

- While the SOFC-cogeneration device operates at its rated electrical output, the temperature of the water supplied to the gas-to-water heat exchanger will be varied from $10^{\circ} \mathrm{C}$ to $90^{\circ} \mathrm{C}$ in a number of steps. Sufficient time will be allowed for conditions to stabilize between each step change. The flow rate of the water through the heat exchanger will remain constant at the manufacturer's recommended flow rate. The test will be repeated at the minimum and maximum recommended flow rates.

- While the SOFC-cogeneration device operates at its rated electrical output, the flow rate of the water supplied to the gas-to-water heat exchanger will be varied from $50 \%$ of the manufacturer's recommended flow rate to $200 \%$ in a number of steps. Sufficient time will be allowed for conditions to stabilize between each step change. The temperature of the water supplied to the heat exchanger will remain constant at $50^{\circ} \mathrm{C}$. The test will be repeated for a supply water temperature of $5^{\circ} \mathrm{C}$ and again for a supply water temperature of $80^{\circ} \mathrm{C}$.

- The above two test sequences will be repeated at $10 \%, 25 \%, 50 \%$, and $75 \%$ of the rated electrical output.

Using Equations 22 and 23, the measured temperature and flow data from these tests will lead to the derivation of $(U A)_{\text {eff }}$ for a large combination of water and product gas flow rates. Selected data from this set will be used to regress the required inputs to the model, that is, the $h x_{s, i}$ coefficients of Equation 27.

Similar approaches will used to calibrate other model inputs, such as $\varepsilon_{i}$ coefficients of Equation 11, the $a_{i}$ coefficients of Equations 13 and 14, and $(U A)_{a u x}$ of Equation 18.

\section{Validation}

Judkoff et al. (1983) classified internal sources of errors in building simulation programs as follows:

- Differences between the actual thermal transfer mechanisms taking place in reality and the simplified model of those physical processes in the simulation.

- Errors or inaccuracies in the mathematical solution of the models.

- Coding errors.

Judkoff and Neymark (1995) propose a pragmatic approach composed of three primary validation constructs to check for these internal errors. These are:

- Analytical verification

- Empirical validation

- Comparative testing

With analytical verification, the program output is compared to a well-known analytical solution for a problem that isolates a single heat transfer mechanism. Typically this necessitates very 
simple boundary conditions. Although analytical verification is limited to simple cases for which analytic solutions are known, it provides an exact standard for comparison. Program outputs are compared to monitored data with empirical validation. The design and operation of experiments leading to high-quality data sets are complex and expensive, thus restricting this approach to a limited number of cases. A program is compared to itself or to other programs with comparative testing. This includes both sensitivity testing and inter-model comparisons. This approach enables inexpensive comparisons at many levels of complexity.

A general principle applies to all three validation constructs. The simpler and more controlled the test case, the easier it is to identify and diagnose sources of error. Realistic cases are suitable for testing the interactions between algorithms but are less useful for identifying and diagnosing errors.

A validation program following the structure outlined above has been designed for the SOFC cogeneration model described in this paper. Since the model has been independently implemented into a number of building simulation programs, emphasis is placed upon inter-model comparative testing to identify coding errors and errors or inaccuracies in the mathematical solution of the models. Empirical validation is used to assess the validity of the mathematical model to simulate the performance of actual SOFC-cogeneration devices through the comparisons with measurements taken in laboratory situations. The third validation construct, analytical validation, is not employed due to the complex nature of the device and the lack of appropriate analytic solutions for the relevant thermodynamic processes. This section provides a succinct overview of this validation program, although the full treatment of this topic will be the subject of subsequent papers.

A series of empirical validation test cases will be developed by drawing from the same experimental programme that is used to calibrate the model. For each empirical test case the pertinent model inputs and boundary conditions will be prescribed in an unambiguous manner. This will enable a direct comparison of model predictions with measurements. These input data will be derived from the experiments using calibration techniques as outlined above. However, it is important to note that the data that will be used to calibrate the model will not subsequently be used for comparison with model predictions. Rather, those measured data that are compared with model predictions will be extracted from the same experimental programme that provide the calibration data, but will represent different operating points.

A suite of carefully constructed test cases that attempt to isolate individual aspects of the model is under development for inter-program comparative testing. Each case is described in sufficient detail to enable simulations to be performed with the various building simulation platforms that include the Annex 42 SOFC-cogeneration model. By equivalencing the model inputs, each simulation program should produce identical or near-identical results. Thus, by comparing program-to-program results, coding errors, erroneous assumptions taken during model implementation, and errors in mathematical solution methods can be identified, diagnosed, and subsequently repaired.

An example diagnostic test from the inter-program comparative suite is provided in Figure 9. This test focuses upon specific terms that comprise the energy balance for the FCPM (refer to Equation 10). Specifically, it is configured to nullify all terms in the energy balance except for those that represent the enthalpy carried into the control volume by the air and fuel, the electrical production, and the enthalpy of the hot exhaust gases exiting the control volume. This test compares predictions of the temperature of the hot exhaust gases from two simulations that differ only in the way the air supply rate is calculated (refer to Equations 13 and 14). Figure 9 includes the results from four independent implementations of the model into four simulation environments. As can be seen from the figure, there is excellent (but not perfect) agreement between these four implementations. 


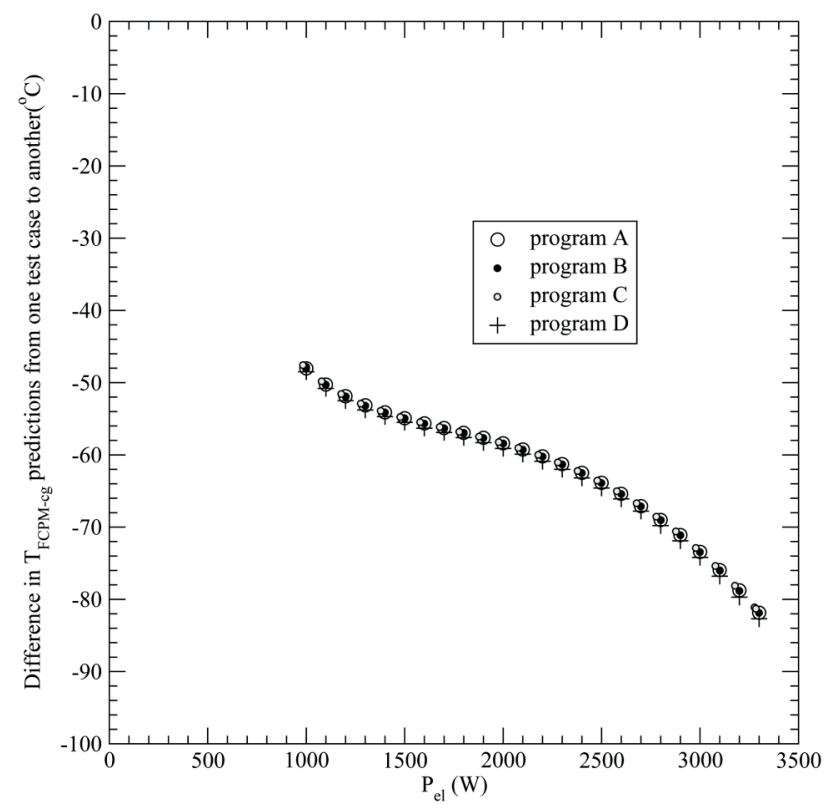

Figure 9. Example inter-program comparative test.

\section{CONCLUSIONS}

This paper has described a mathematical model for simulating the performance of SOFC-cogeneration systems. This is a system-level model that considers the thermodynamic performance of all components that consume energy and produce the SOFC-cogeneration device's thermal and electrical output. This model is appropriate for use in whole-building simulation programs, where it can be coupled to models of associated HVAC plant components (e.g., hot water storage, hydronic heating systems, thermally activated cooling systems) and models that predict the building's thermal and electrical demands. Only by considering these interactions between the building thermal, HVAC, electrical, and generation domains on a time-step basis can simulation accurately assess the potential energy and greenhouse gas emissions benefits of this nascent technology.

The methods used to resolve the energy balances representing three of the critical control volumes (the fuel cell power module or FCPM, the auxiliary burner, and the exhaust-gas-to-water heat exchanger) have been elaborated in detail. The control volume representing the FCPM encapsulates a number of components including the stack, afterburner, fuel preheater, fuel reformer, etc. Consequently, the methods outlined in this paper to treat the FCPM could be easily adapted to represent the performance of cogeneration systems based upon other fuel cell technologies, such as polymer electrolyte membrane fuel cells (PEMFC). The model topology outlined in this paper contains some aspects that are specific to SOFC-cogeneration devices, which have high-temperature product gases. However, work is underway to adapt the model to also treat low-temperature PEMFC-cogeneration devices.

This paper has also described how the model can be implemented into a building simulation program and has demonstrated how the model can be used to simulate the performance of a hypothetical SOFC-cogeneration device that is coupled to a house's space-heating system. 
Finally, the paper has concluded by describing ongoing efforts to both calibrate and validate the model. Future papers will report these results as well as analyses of actual SOFC-cogeneration devices under different operating scenarios.

\section{ACKNOWLEDGMENTS}

The work described in this paper was undertaken as part of the International Energy Agency's Energy Conservation in Building and Community Systems Programme's Annex 42 The Simulation of Building-Integrated Fuel Cell and Other Cogeneration Systems (www.cogen-sim.net). The Annex is an international collaborative research effort, and the authors gratefully acknowledge the indirect or direct contributions of the other Annex participants. The contributions of simulation results for the inter-program comparative test illustrated in Figure 9 by the following individuals are specifically acknowledged: Brent Griffith (National Renewable Energy Laboratory), Teemu Vesanen (Technical Research Centre of Finland), and Sébastien Lerson (University of Liège).

\section{NOMENCLATURE}

\begin{tabular}{|c|c|c|c|c|c|}
\hline$\dot{H}_{i}$ & $=$ & $\begin{array}{l}\text { total enthalpy flow rate of constit- } \\
\text { uent } i, \mathrm{~W}\end{array}$ & $N_{\text {stops }}$ & $=$ & $\begin{array}{l}\text { number of times SOFC-cogenera- } \\
\text { tion device has been stopped and }\end{array}$ \\
\hline$h_{i}$ & $=$ & molar enthalpy of constituent $i$, & & & restarted since its initiation \\
\hline$\Delta \hat{h}_{i}^{o}$ & $=$ & $\begin{array}{l}\mathrm{J} / \mathrm{kmol} \\
\text { standard molar enthalpy of forma- } \\
\text { tion of gas } i, \mathrm{~J} / \mathrm{kmol}\end{array}$ & $q_{\text {skin-loss }}$ & $=$ & $\begin{array}{l}\text { performance degradation associ- } \\
\text { ated with stop-start cycling } \\
\text { parasitic thermal losses from }\end{array}$ \\
\hline$\Delta_{f} H_{i}^{o}$ & $=$ & $\begin{array}{l}\text { total flow rate of standard } \\
\text { enthalpy of formation of gas } i, \mathrm{~W}\end{array}$ & $q_{\text {aux-skin-loss }}$ & $=$ & $\begin{array}{l}\text { M to containing room, } \mathrm{W} \\
\text { sitic thermal losses from auxil- }\end{array}$ \\
\hline$\hat{c}_{P_{i}}$ & $=$ & $\begin{array}{l}\text { molar heat capacity of constituent } i \text {, } \\
\mathrm{J} / \mathrm{kmol} \cdot \mathrm{K}\end{array}$ & $(U A)_{a u x}$ & $=$ & $\begin{array}{l}\text { iary burner to containing room, W } \\
\text { heat loss coefficient between aux- }\end{array}$ \\
\hline$L H \underbrace{}_{O}$ & $=$ & lower heating value, $\mathrm{J} / \mathrm{kmol}$ & & & $\begin{array}{l}\text { 1liary burner and containing room, } \\
\mathrm{W} / \mathrm{K}\end{array}$ \\
\hline$\Delta \hat{h}_{\mathrm{H}_{2} \mathrm{O}, f g}^{o}$ & $=$ & $\begin{array}{l}\text { latent heat of vaporization of } \\
\text { water at standard state, } \mathrm{J} / \mathrm{kmol}\end{array}$ & $(U A)_{e f f}$ & $=$ & $\begin{array}{l}\text { effective product of heat } \\
\text { exchanger's heat transfer coeffi- }\end{array}$ \\
\hline$P_{e l}$ & $=$ & $\begin{array}{l}\text { net DC electric power produced } \\
\text { by FCPM, W }\end{array}$ & $\varepsilon_{H X}$ & $=$ & $\begin{array}{l}\text { cient and area, W/K } \\
\text { effectiveness of heat exchanger }\end{array}$ \\
\hline$P_{e l, a n c-A C}$ & $=$ & $\begin{array}{l}\text { power draw of AC-powered ancil- } \\
\text { lary devices within FCPM, W }\end{array}$ & $q_{H X}$ & $=$ & $\begin{array}{l}\text { heat transfer from hot product } \\
\text { gases to water, W }\end{array}$ \\
\hline$P_{e l, a u x-a n c}$ & $=$ & $\begin{array}{l}\text { power draw of auxiliary burner's } \\
\text { ancillary devices, W }\end{array}$ & $\dot{N}_{i}$ & $=$ & $\begin{array}{l}\text { molar flow rate of constituent } i \text {, } \\
\mathrm{kmol} / \mathrm{s}\end{array}$ \\
\hline$\varepsilon_{e l}$ & & $\begin{array}{l}\text { electrical efficiency relative to } \\
\text { fuel's LHV }\end{array}$ & $\begin{array}{l}T \\
\lambda\end{array}$ & $\begin{array}{l}= \\
=\end{array}$ & $\begin{array}{l}\text { temperature, } \mathrm{K} \text { or }{ }^{\circ} \mathrm{C} \\
\text { excess air ratio }\end{array}$ \\
\hline
\end{tabular}

\section{Subscripts}

\begin{tabular}{|c|c|c|}
\hline fuel & $=$ & fuel entering FCPM \\
\hline$f$ & $=$ & $\begin{array}{l}\text { fuel entering auxiliary } \\
\text { burner }\end{array}$ \\
\hline air & $=$ & air entering FCPM \\
\hline$a$ & $=$ & $\begin{array}{l}\text { air entering auxiliary } \\
\text { burner }\end{array}$ \\
\hline liq-water & $=$ & liquid water \\
\hline$F C P M-c g$ & $=$ & $\begin{array}{l}\text { product gases exiting } \\
\text { FCPM }\end{array}$ \\
\hline
\end{tabular}

$\begin{array}{ll}\text { products-of-reactions }= & \begin{array}{l}\text { products of electrochemi- } \\ \text { cal and combustion reac- } \\ \text { tions of fuel and air }\end{array} \\ \text { unreacted-fuel+air } & =\begin{array}{l}\text { unreacted fuel and air con- } \\ \text { stituents }\end{array} \\ = & \text { water vapor generated } \\ & \text { from liquid water supply } \\ \mathrm{H}_{2} \mathrm{O} \text {, vap } & =\text { minimum } \\ \text { min } & \text { condensation of water } \\ \mathrm{H}_{2} \mathrm{O} \text {-cond } & \text { from the gas stream } \\ \text { cond-threshold } & =\text { threshold for condensation }\end{array}$

Superscript

$S$

$=$ stoichiometric 


\section{REFERENCES}

Beale, S.B., Y. Lin, S.V. Zhubrin, and W. Dong. 2003. Computer methods for performance prediction in fuel cells. J. Power Sources 118:79-85.

Beausoleil-Morrison, I., D. Cuthbert, G. Deuchars, and G. McAlary. 2002. The simulation of fuel cell cogeneration systems within residential buildings. Proc. eSim 2002, Montréal, Canada, pp. 40-47.

Beausoleil-Morrison, I., A. Schatz, and F. Maréchal. 2005. A proposed system-level model for simulating the thermal and electrical production of solid-oxide fuel cell residential cogeneration devices within whole-building simulation. Proc. Building Simulation 2005, Montréal, Canada, pp. 55-62.

Beausoleil-Morrison, I. 2005. Model specifications for an SOFC-cogeneration device. IEA/ECBCS Annex 42 Working Document.

Bove, R., P. Lungh, and N.M. Sammes. 2005a. SOFC mathematical model for systems simulations. Part 1: from a micro-detailed to macro-black-box model. Int J Hydrogen Energy 30:181-87.

Bove, R., P. Lungh, and N.M. Sammes. 2005b. SOFC mathematical model for systems simulations. Part 2: Definition of an analytical model. Int J Hydrogen Energy 30:189-200.

Braun, R.J. 2002. Optimal design and operation of solid oxide fuel cell systems for small-scale stationary applications. PhD thesis, University of Wisconsin-Madison.

Chan, S.H., and O.L. Ding. 2005. Simulation of a solid oxide fuel cell power system fed by methane. Int $J$ Hydrogen Energy 30:167-79.

Clarke, J.A. 2001. Energy Simulation in Building Design, 2d ed. Oxford, UK: Butterworth-Heinemann.

Diethelm, R. 2004. Cheaper, compacter, and lighter through greater system integration. Sulzer Technical Review 4:14-16.

Dorer, V., R. Weber, and A. Weber. 2005. Performance assessment of fuel cell micro-cogeneration systems for residential buildings. Energy and Buildings 37:1132-46.

Ellis, M.W., and M.B. Gunes. 2002. Status of fuel cell systems for combined heat and power applications in buildings. ASHRAE Transactions 108 (1):1032-44.

ESRU. 2002. The ESP-r System for Building Energy Simulations: User Guide Version 10 Series. ESRU Manual U02/1, University of Strathclyde, Glasgow, UK.

Hawkes, A., and M. Leach. 2005. Solid oxide fuel cell systems for residential micro-combined heat and power in the UK: Key economic drivers. J Power Sources 149:72-83.

Hensen, J.L.M. 1991. On the thermal interaction of building structure and heating and ventilation system. $\mathrm{PhD}$ thesis, Eindhoven University of Technology, The Netherlands.

Judkoff, R., D. Wortman, B. O’Doherty, and J. Burch. 1983. A methodology for validating building energy analysis simulations. Report TR-254-1508, Solar Energy Research Institute, Golden, CO.

Judkoff, R., and J. Neymark. 1995. International Energy Agency Building Energy Simulation Test (BESTEST) and Diagnostic Method, IEA Energy Conservation in Buildings and Community Systems Programme Annex 21 Subtask C and IEA Solar Heating and Cooling Programme, Task 12, Subtask B.

Karakoussis, V., M. Leach, R. van der Vorst, D. Hart, J. Lane, P. Pearson, and J. Kilner. 2000. Environmental emissions of SOFC and SPFC system manufacture and disposal, Report F/01/00164/REP to British Department of Trade and Industry.

Knight, I., and V.I. Ugursal. 2005. Residential cogeneration systems: A review of the current technologies, IEA/ECBCS Annex 42 Report.

NIST. 2003. Chemistry WebBook, National Institute of Standards and Technology Standard Reference Database Number 69, March 2003 Release, http://webbook.nist.gov/chemistry/.

Petruzzi, L., S. Cocchi, and F. Fineschi. 2003. A global thermo-electrochemical model for SOFC systems design and engineering. Journal of Power Sources 118:96-107.

Reynolds, W.C., and H.C. Perkins. 1977. Engineering Thermodynamics. New York: McGraw-Hill.

Sicre, B., A. Bühring, and B. Platzer. 2005. Energy and financial performance of micro-CHP in connection with high-performance buildings. Proc. Building Simulation 2005, Montréal, Canada, pp. 1139-46. 
Singhal, S.C., and K. Kendall. 2003. High Temperature Solid Oxide Fuel Cells: Fundamentals, Design, and Applications. Oxford, UK: Elsevier.

Van herle, J., F. Maréchal, S. Leuenberger, Y. Membrez, O. Bucheli, and D. Favrat. 2004. Process flow model of solid oxide fuel cell system supplied with sewage biogas. J. Power Sources 131:127-41.

Weber, C., F. Maréchal, S. Kraines, and D. Favrat. 2005. Optimization of an SOFC-based decentralized polygeneration system for providing energy services in an office-building in Tokyo. Applied Thermal Engineering (in press). 
